\title{
Two New 11(15 $\rightarrow 1)$ Abeotaxanes with a 2,20-Epoxy Ring from the Needles of Taxus canadensis
}

\author{
Man-Li Zhang ${ }^{\mathrm{a}}$, Jing Zhang ${ }^{\mathrm{b}}$, Mei Dong ${ }^{\mathrm{a}}$, Shu-Hua Feng ${ }^{\mathrm{c}}$, Chang-Hong Huo ${ }^{\mathrm{a}}$, \\ Françoise Sauriol ${ }^{\mathrm{d}}$, Qing-Wen Shi ${ }^{\mathrm{a}, *}$, Yu-Cheng Gu ${ }^{\mathrm{e}}$, Hiromasa Kiyota ${ }^{\mathrm{f}, *}$, \\ and Bin Cong ${ }^{\mathrm{a}, *}$
}

a School of Pharmaceutical Sciences and College of Basic Medical Sciences, Hebei Medical University, 361 Zhongshan East Road, 050017, Shijiazhuang, Hebei Province,

P. R. China. E-mail: shiqingwen@hebmu.edu.cn

b The Third Affiliated Hospital of Hebei Medical University, 050000, Shijiazhuang, Hebei

Province, P. R. China

c Drug Control Institute of Hebei Province, Fuqing Dajie, 050012, Shijiazhuang, Hebei Province, P. R. China

d Department of Chemistry, Queen's University, Kingston, Ontario K7L 3N6, Canada

e Syngenta Jealott's Hill International Research Centre, Bracknell, Berkshire RG42 6EY, UK

f Department of Bioscience and Biotechnology for Future Bioindustry, Graduate School of Agricultural Science, Tohoku University, 1-1 Tsutsumidori-Amamiya, Aoba-ku, Sendai, 981-8555, Japan. Fax: +812271787 85. E-mail: kiyota@biochem.tohoku.ac.jp

* Authors for correspondence and reprint requests

Z. Naturforsch. 64c, 43-48 (2009); received May 13/July 28, 2008

Two 11(15 $\rightarrow 1$ ) abeotaxanes having a tetrahydrofuran ring along the carbon atoms C-2, C-3, C-4, C-20 were identified for the first time from the needles of the Canadian yew, Taxus $\mathrm{ca}$ nadensis. The compounds could be identified as $4 \alpha, 10 \beta, 13 \alpha$-triacetoxy-15-benzoyloxy- $2 \alpha, 20 \beta$ epoxy-11(15 $\rightarrow 1)$ abeotax-11-ene-5 $\alpha, 7 \beta, 9 \alpha$-triol (1) and $4 \alpha, 7 \beta, 9 \alpha, 10 \beta, 15$-pentaacetoxy-2 $\alpha, 20 \beta$ epoxy-11 $(15 \rightarrow 1)$ abeotax-11-ene-5 $\alpha, 13 \alpha$-diol $(2)$ on the basis of 1D-, 2D-NMR evidence and high-resolution FABMS analysis. Compound 1 showed weak growth inhibitory activities against T-98 and MM1-CB cells in vitro.

Key words: Taxus canadensis, 11(15 $\rightarrow 1)$ Abeotaxanes, Structure Elucidation, Cell Growth Inhibition

\section{Introduction}

The discovery of Taxol ${ }^{\circledR}$ (paclitaxel) has stimulated great renewed interest in the analysis of the various Taxus species with the attention to find an alternative source of this and related compounds with improved activity. Although more than 500 taxanes have been isolated to date (Baloglu and Kingston, 1999), a number of new taxanes have been reported recently (Shi and Kiyota, 2005; Shi et al., 2007), and there are still new ones waiting for isolation and structural characterization. The Canadian yew, Taxus canadensis Marsh (Taxaceae), a low trailing bush which is very common in Quebec, has been thoroughly investigated since 1992. It has been shown to be an interesting plant with unusual taxanes specific to this yew (Dong et al., 2008).

In the present publication we are reporting the characterization of two new $11(15 \rightarrow 1)$ abeotax- anes, $\mathbf{1}$ and $\mathbf{2}$, from the needles of the Canadian yew. Their chemical structures were rigorously elucidated using 1D-, 2D-NMR and HR-FABMS data (Fig. 1).

\section{Results and Discussion}

Taxane $\mathbf{1}$ was obtained as an amorphous solid from the methanol extract of the T. canadensis needles. The molecular formula of $\mathbf{1}, \mathrm{C}_{33} \mathrm{H}_{42} \mathrm{O}_{12}$, was deduced from combined analysis of HR-FABMS at $m / z 669.2307[\mathrm{M}+\mathrm{K}]^{+}$(calcd. for $\mathrm{C}_{33} \mathrm{H}_{42} \mathrm{O}_{12} \mathrm{~K}$, 669.2313) and ${ }^{13} \mathrm{C}$ NMR data. Thirteen indices of hydrogen deficiency were calculated from the molecular formula. The ${ }^{1} \mathrm{H}$ NMR spectrum (Table I) exhibited four three-proton signals due to the four methyl groups at $\delta 1.77,1.80,1.88$ and 1.23 , and three acetyl methyl group signals at $\delta$ $1.76,2.06$ and 2.05 , which were verified by the observation of ${ }^{13} \mathrm{C}$ NMR signals of carbonyl car- 


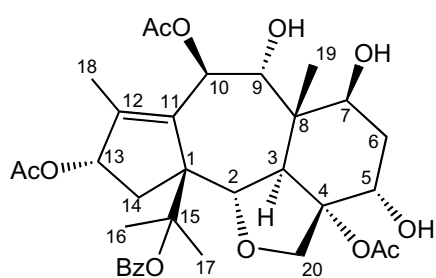

1

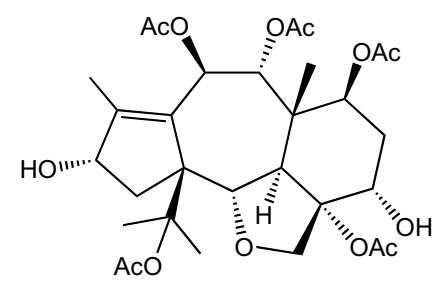

2

Fig. 1. Chemical structures of compounds $\mathbf{1}$ and $\mathbf{2}$.

bon atoms at $\delta 169.4,170.5$ and 172.0 as well as the corresponding methyl groups of acetates at $\delta$ 21.0, 21.8 and 21.7. These signals together with its plant origin consideration suggested that $\mathbf{1}$ is a taxane derivative (Appendino, 1995). Analysis of the ${ }^{1} \mathrm{H},{ }^{13} \mathrm{C}$ NMR data and 2D-NMR spectral data disclosed 33 carbon signals due to three acetyl, one benzoyl, four methyl, six oxymethine, one methine, two methylene, one oxymethylene groups, six quaternary carbon atoms including two $\mathrm{sp}^{2}$ (fully substituted olefinic carbon atoms) and four $\mathrm{sp}^{3}$ hybrid carbon atoms. To accommodate thirteen degrees of unsaturation, 1 apparently contains four rings. The chemical shift of C-1 at $\delta 65.1$, an unusual downfield chemical shift for an unoxygenated quaternary carbon atom together with absent long-range correlations between C-11 and Me-16, Me-17, which were always observed in the HMBC experiment in a 6/8/6-membered ring taxane, strongly indicated that taxane 1 possesses an $11(15 \rightarrow 1)$ rearranged skeleton, $i$. e. a brevifoliol analogue (Appendino, 1995). This conclusion was further verified in the HMBC experiment by long-range correlations between $\mathrm{H}-10$ and $\mathrm{C}-1$ as well as correlations between $\mathrm{H}-14$ and $\mathrm{C}-11$, $\mathrm{C}-12$, which means that both $\mathrm{C}-11$ and $\mathrm{C}-12$ are in three-bond distance to H-14. The tertiary hydroxy group at C-1 was observed from the adjacent quaternary carbon atoms at $\delta 65.1(\mathrm{C}-1)$ and $\delta 87.9$ $(\mathrm{C}-15)$, and cross-peaks from Me-16 ( $\delta$ 1.77) and
Me-17 ( $\delta 1.80)$ to $\mathrm{C}-1$ and $\mathrm{C}-15$ as well as correlations of two geminal methyl groups in the HMBC experiment. The assignments of functional groups on the taxane skeleton were made on the basis of analyses of ${ }^{1} \mathrm{H}-{ }^{1} \mathrm{H}$ COSY and HMBC correlations. The signal at $\delta 2.35(1 \mathrm{H}$, br.d, $J=7.3 \mathrm{~Hz})$, which is typical of an $\mathrm{H}-3 \alpha$ ring junction proton in taxane diterpenes, correlated with only one signal at $\delta$ $5.04(1 \mathrm{H}, \mathrm{d}, J=7.5 \mathrm{~Hz})$ in the ${ }^{1} \mathrm{H}-{ }^{1} \mathrm{H}$ COSY spectrum. Accordingly, this was assigned to H-2. Similarly, the signal at $\delta 4.21(1 \mathrm{H}, \mathrm{dd}, J=11.0,7.6 \mathrm{~Hz})$ was assigned to $\mathrm{H}-5 \beta$. The chemical shift of $\mathrm{H}-5 \beta$ implied that a free hydroxy group is connected to $\mathrm{C}-5$. Using $\mathrm{H}-5 \beta$ as reference, the spin system from $\mathrm{H}-5$ to $\mathrm{H}-6$ and $\mathrm{H}-7$ was readily interpreted. The chemical shift of H-7 $(\delta 4.00,1 \mathrm{H}, \mathrm{dd}, J=$ $12.5,2.5 \mathrm{~Hz}$ ) demonstrated that $\mathrm{C}-7$ bears a free hydroxy function. The signal at $\delta 5.70(1 \mathrm{H}, \mathrm{t}, J=$ 7.2 Hz) exhibited a long-range $\mathrm{C}-\mathrm{H}$ correlation with Me-18 in the HMBC spectrum, and crosspeaks with geminal protons of a methylene group at $\delta 2.76(1 \mathrm{H}, \mathrm{dd}, J=14.7,7.2 \mathrm{~Hz}, \mathrm{H}-14 \alpha)$ and 2.20 $(1 \mathrm{H}, \mathrm{m}, \mathrm{H}-14 \beta)$ in the ${ }^{1} \mathrm{H}-{ }^{1} \mathrm{H}$ COSY map were assigned to $\mathrm{H}-13$. The chemical shift of $\mathrm{H}-13$ suggested that an acetyl group is positioned at C-13. A set of coupling systems at $\delta 3.81(1 \mathrm{H}, \mathrm{d}, J=$ $3.9 \mathrm{~Hz}$ ) correlated with C-3, C-8, C-10 and C-11, and that at $6.16(1 \mathrm{H}, \mathrm{d}, J=3.9 \mathrm{~Hz})$ correlated with C-1, C-8, C-9, C-11, C-12. A carbonyl carbon atom was attributed to $\mathrm{H}-9$ and $\mathrm{H}-10$, respectively, and an acetyl group is attached to $\mathrm{C}-10$. Another pair of spin system, resonating at $\delta 4.41(1 \mathrm{H}, \mathrm{d}, J=$ $11.4 \mathrm{~Hz})$ and $3.76(1 \mathrm{H}, \mathrm{d}, J=11.4 \mathrm{~Hz})$, showed cross-peaks with C-4 in the HMBC experiment and was assigned to $\mathrm{H}-20 \alpha$ and $\mathrm{H}-20 \beta$, respectively. The deshielded chemical shifts of C-4 $(\delta 94.9)$ and $\mathrm{C}-15(\delta 87.9)$ indicated that a tetrahydrofuran ring along carbon atoms $\mathrm{C}-2, \mathrm{C}-3, \mathrm{C}-4$ and $\mathrm{C}-20$ is formed and the remaining acetyl and benzoyl moieties are attached at C-4 and C-15 (Zhang et al., 1995; Shen et al., 2002). The NOE correlation between the ortho-protons of the benzoyl group and $\mathrm{H}-2, \mathrm{H}-13$ and $\mathrm{H}-19$ not only assigned the benzoyl group to $\mathrm{C}-15$ but also confirmed that the C- 1 benzoyl dimethyl carbinol moiety is in $\beta$-orientation. The relative stereochemistry of taxane 1 was deduced using the information contained in the NOESY spectrum and by comparing its coupling constants with its analogue (Shen et al., 2002) (Fig. 2). The NOESY correlations of $\mathrm{H}-2 / \mathrm{Me}-17$, Me-19, and H-9/Me-19 in 1 suggested that $\mathrm{H}-2, \mathrm{H}-9, \mathrm{Me}-19$ are in $\beta$-orientation. Corre- 
Table I. The ${ }^{1} \mathrm{H}$ and ${ }^{13} \mathrm{C}$ NMR data of $\mathbf{1}$ in $\mathrm{CDCl}_{3}\left(500 \mathrm{MHz}\right.$ for ${ }^{1} \mathrm{H}, 125 \mathrm{MHz}$ for $\left.{ }^{13} \mathrm{C}\right)$.

\begin{tabular}{|c|c|c|c|c|c|}
\hline Position & $\delta_{\mathrm{H}}\left(\right.$ mult $\left.^{\mathrm{a}}\right)$ & $J[\mathrm{~Hz}]$ & $\delta_{\mathrm{C}}^{\mathrm{b}}$ & HMBC & NOESY $^{\mathrm{c}}$ \\
\hline 1 & - & & 65.1 & & \\
\hline 2 & $5.04(\mathrm{~d})$ & 7.5 & 80.0 & $8,14,15$ & $3^{\mathrm{m}}, 17^{\mathrm{s}}, 19^{\mathrm{s}}, 20 \beta^{\mathrm{s}}, \mathrm{Ph}-o^{\mathrm{s}}$ \\
\hline 3 & 2.35 (br.d) & $\sim 7.3$ & 49.3 & & $2^{\mathrm{m}}, 7^{\mathrm{s}}, 14 \alpha^{\mathrm{s}}$ \\
\hline 4 & - & & 94.9 & & \\
\hline 5 & $4.21(\mathrm{dd})$ & $11.0,7.6$ & 72.1 & & $6 a^{s}, 7^{m}$ \\
\hline $6 a$ & $2.02(\mathrm{~m})$ & & 32.8 & & $5^{s}$ \\
\hline $6 b$ & $1.89(\mathrm{~m})$ & & & & $19^{\mathrm{s}}$ \\
\hline 7 & $4.00(\mathrm{dd})$ & $12.5,2.5$ & 68.6 & & $3^{\mathrm{s}}, 5^{\mathrm{m}}$ \\
\hline 8 & - & & 44.4 & & \\
\hline 9 & $3.81(\mathrm{~d})$ & 3.9 & 73.8 & $3,8,10,11$ & $10^{\mathrm{s}}, 19^{\mathrm{s}}$ \\
\hline 10 & $6.16(d)$ & 3.9 & 72.4 & $1,8,9,11,12,169.4$ & $9^{\mathrm{s}}, 18^{\mathrm{s}}$ \\
\hline 11 & - & & 135.0 & & \\
\hline 12 & - & & 144.7 & & \\
\hline 13 & $5.70(\mathrm{t})$ & 7.2 & 81.9 & & $14 \beta^{\mathrm{m}}, 17^{\mathrm{s}}, 18^{\mathrm{m}}, \mathrm{Ph}-o^{\mathrm{m}}$ \\
\hline $14 \alpha$ & $2.76(\mathrm{dd})$ & $14.7,7.2$ & 35.5 & $11,12,15$ & $3^{\mathrm{s}}, 14 \beta^{\mathrm{s}}$ \\
\hline $14 \beta$ & $2.20(\mathrm{~m})$ & & & $1,2,15$ & $13^{\mathrm{m}}, 14 \alpha^{\mathrm{s}}, 16^{\mathrm{m}}, 17^{\mathrm{s}}$ \\
\hline 15 & - & & 87.9 & & \\
\hline 16 & $1.77(\mathrm{~s})$ & & 25.6 & $1,15, \mathrm{Me}$ & $14 \beta^{\mathrm{m}}, 17^{\mathrm{s}}$ \\
\hline 17 & $1.80(\mathrm{~s})$ & & 24.1 & $1,15, \mathrm{Me}$ & $2^{\mathrm{s}}, 13^{\mathrm{s}}, 14 \beta^{\mathrm{s}}, 16^{\mathrm{s}}$ \\
\hline 18 & $1.88(\mathrm{~s})$ & & 13.3 & $11,12,13$ & $10^{\mathrm{s}}, 13^{\mathrm{m}}$ \\
\hline 19 & $1.23(\mathrm{~s})$ & & 13.5 & $3,7,8,9$ & $2^{\mathrm{s}}, 6 \mathrm{~b}^{\mathrm{s}}, 9^{\mathrm{s}}, 20 \beta^{\mathrm{s}}, \mathrm{Ph}-o^{\mathrm{m}}$ \\
\hline $20 \alpha$ & $4.41(\mathrm{~d})$ & 11.4 & 72.6 & 3,4 & $20 \beta^{\mathrm{s}}$ \\
\hline $20 \beta$ & $3.76(d)$ & 11.4 & & 4 & $2^{\mathrm{s}}, 19^{\mathrm{s}}, 20 \alpha^{\mathrm{s}}$ \\
\hline \multirow[t]{3}{*}{ Ac } & $1.76(\mathrm{~s})$ & & 21.0 & 169.4 & \\
\hline & $2.06(\mathrm{~s})$ & & 21.8 & 170.5 & \\
\hline & $2.05(\mathrm{~s})$ & & 21.7 & 172.0 & \\
\hline \multicolumn{6}{|l|}{$\mathrm{Bz}$} \\
\hline Ipso & & & 165.6 & & \\
\hline$o$ & $7.93(d)$ & 7.8 & 129.4 & 165.6 & $2^{\mathrm{s}}, 13^{\mathrm{w}}, 19^{\mathrm{m}}, \mathrm{Ph}-m^{\mathrm{s}}$ \\
\hline$m$ & $7.39(\mathrm{t})$ & 7.2 & 128.1 & & $\mathrm{Ph}-o^{\mathrm{s}}$ \\
\hline$p$ & $7.51(\mathrm{t})$ & 7.2 & 132.2 & & \\
\hline
\end{tabular}

a Mutiplicity: s, singlet; d, doublet; dd, doublet of doublets; m, multiplet.

b The ${ }^{13} \mathrm{C}$ chemical shifts were extracted from the HMQC experiment $( \pm 0.2 \mathrm{ppm})$.

c NOESY intensities are marked as strong (s), medium (m), or weak (w).

lations between $\mathrm{H}-3 / \mathrm{H}-7$ and $\mathrm{H}-10 / \mathrm{Me}-18$ agreed with the $\alpha$-configuration of $\mathrm{H}-3, \mathrm{H}-7$, and $\mathrm{H}-10$. The small coupling constant between H-9 and $\mathrm{H}-10(J=3.9 \mathrm{~Hz})$ resulted from the anti-orientation of hydroxy and acetoxy groups at C-9 and at $\mathrm{C}-10$ and the gauche-relationship of $\mathrm{H}-9$ and $\mathrm{H}-10$, which leads to a dihedral angle of $45^{\circ}$ between H-9 and H-10 (Fuji et al., 1995). Intense cross-peaks between $\mathrm{H}-9$ and $\mathrm{H}-10$ in the NOESY spectrum of 1 were also observed. A chair-like conformation of ring $\mathrm{B}$ and ring $\mathrm{C}$ was consistent with the results from NOESY experiments. The large coupling constants of $\mathrm{H}-5(J=7.6,11.0 \mathrm{~Hz})$ suggested that the C-5 hydroxy group should be in $\alpha$-orientation. This might be explained by calculations of the dihedral angles of H-5/C-5/C- 6 /
H-6B $\left(30^{\circ}\right)$ and H-5/C-5/C-6/H-6A $\left(165^{\circ}\right)$. Taking all above arguments into account, the structure of 1 was determined as $4 \alpha, 10 \beta, 13 \alpha$-triacetoxy-15benzoyloxy- $2 \alpha, 20 \beta$-epoxy-11(15 $\rightarrow 1)$-abeotax-11ene-5 $\alpha, 7 \beta, 9 \alpha$-triol. This is the first example of a taxane isolated from the needles of Canadian yew with a $2 \alpha, 20 \beta$-epoxy ring and a benzoyloxy moiety at C-15.

The molecular formula of $\mathbf{2}, \mathrm{C}_{30} \mathrm{H}_{42} \mathrm{O}_{13}$, was derived from combined analysis of HR-FABMS at $m / z 633.2523[\mathrm{M}+\mathrm{Na}]^{+}$(calcd. for $\mathrm{C}_{30} \mathrm{H}_{42} \mathrm{O}_{13} \mathrm{Na}$, 633.2523) and 649.2255 [M+K $]^{+}$(calcd. for $\left.\mathrm{C}_{30} \mathrm{H}_{42} \mathrm{O}_{13} \mathrm{~K}, 649.2262\right)$ as well as its ${ }^{13} \mathrm{C}$ NMR data. The hydrogen deficiency was calculated as ten from the molecular formula. The ${ }^{1} \mathrm{H}$ and ${ }^{13} \mathrm{C}$ NMR spectra of 2 (Table II) showed similarity 


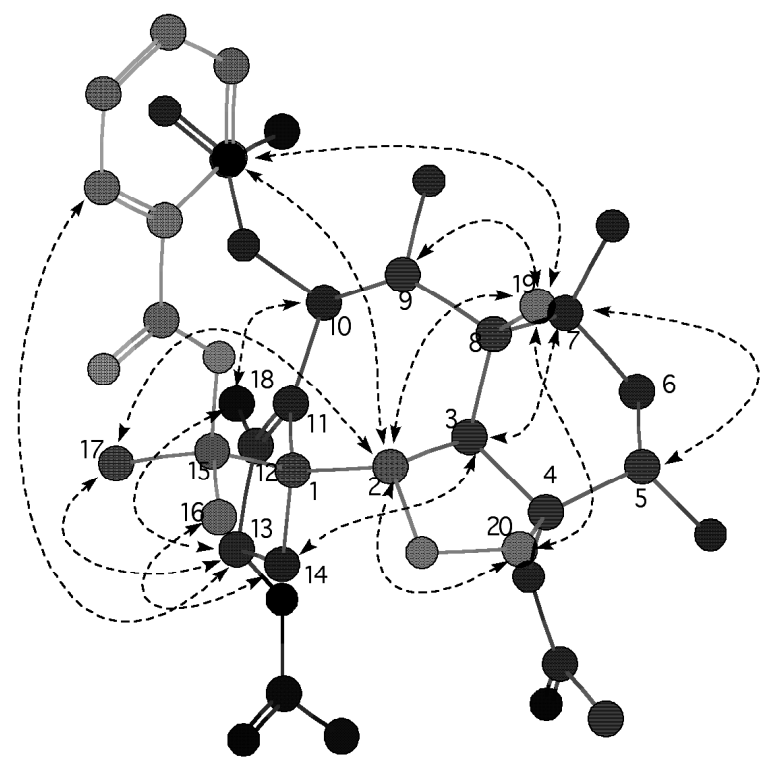

Fig. 2. Relative stereochemistry of 1. Dotted arrows denote NOESY correlations. Most of the protons are omitted for clarity.

with those of $\mathbf{1}$, both of them shared the same $11(15 \rightarrow 1)$ abeotaxane with a $2 \alpha, 20 \beta$-epoxy ring. The major difference was the absence of the benzoyl group. Extensive analysis of 1D- and 2DNMR data of 2 and comparing them with those of $\mathbf{1}$ allowed the assignments of all the functional groups. Thus, the structure of $\mathbf{2}$ was determined to be $4 \alpha, 7 \beta, 9 \alpha, 10 \beta, 15$-pentaacetoxy-2 $\alpha, 20 \beta$-epoxy$11(15 \rightarrow 1)$ abeotax-11-ene- $5 \alpha, 13 \alpha$-diol.

Growth inhibitory activities of $\mathbf{1}$ against human tumour cells were tested (Suzuki and Fuse, 1984; Suzuki et al., 1995; Zhai et al., 2005). 1 showed weak growth inhibitory activities against T-98 $\left(\mathrm{IC}_{50} \sim 100 \mu \mathrm{M}\right)$ and MM1-CB $\left(\mathrm{IC}_{50} \sim 100 \mu \mathrm{M}\right)$ cells while it was inactive against HeLa, HEC-1, SHIN3, HOC-21, HAC-2, HLE, U251-SP, HMV-1, and $\mathrm{KT}$ cells in vitro.

Compounds $\mathbf{1}$ and $\mathbf{2}$ are novel abeotaxane diterpenoids with a rare 2,20-epoxy ring system, which only have been isolated from T. mairei (Shen et al., 2002, 2005). Therefore, the occurrence of compounds $\mathbf{1}$ and $\mathbf{2}$ in the Canadian yew, T. canadensis, may be of chemotaxonomic significance.

\section{Experimental}

\section{General experimental procedures}

Optical rotations: JASCO DIP-370. NMR spectra: Bruker Avance DRX-500 NMR; the chemical shifts were referenced relative to the corresponding residual solvent signals $\left({ }^{1} \mathrm{H}: \delta 7.25 \mathrm{ppm}\right.$ and ${ }^{13} \mathrm{C}: \delta 77.7 \mathrm{ppm}$, respectively). Flash chromatography: Silica gel 60 (230-400 mesh; EM Science). Thin layer chromatography: Silica gel $60 \mathrm{~F}_{254}$ precoated TLC plates $(0.25 \mathrm{~mm}$ or $0.5 \mathrm{~mm}$; EM Science).

\section{Plant material}

The needles of Taxus canadensis Marsh were collected in September 1997 at St.-Jean, Quebec, Canada. Several specimens (under accession voucher number lz97-03) have been deposited in the herbarium of the Montreal Botanical Garden, Montreal, Canada.

\section{Extraction and isolation}

Air-dried needles of Taxus canadensis were ground $(4.0 \mathrm{~kg})$ and extracted with $24 \mathrm{~L}$ of methanol for $1 \mathrm{~d}$ at room temperature. The ground plants were filtered and extracted again with fresh solvent for another three times (each time with $8 \mathrm{~L}$ solvent, total $24 \mathrm{~L}$ ) in $3 \mathrm{~d}$. The combined organic extracts were evaporated under reduced pressure. Water (3 L) was added and lipids were removed by stirring the mixture with hexane $(3 \times$ $3 \mathrm{~L})$. The aqueous phase was then salted $(\mathrm{NaCl}$, $200 \mathrm{~g})$ and extracted with $\mathrm{CH}_{2} \mathrm{Cl}_{2}(4 \times 3 \mathrm{~L})$. The combined $\mathrm{CH}_{2} \mathrm{Cl}_{2}$ extracts were dried with anhydrous sodium sulfate, filtered and evaporated yielding a dark green extract $(115 \mathrm{~g})$. A portion of the $\mathrm{CH}_{2} \mathrm{Cl}_{2}$ extract $(50 \mathrm{~g})$ was subjected to column chromatography (silica gel, $1430 \mathrm{~g}$ ). Elution with a $\mathrm{CH}_{2} \mathrm{Cl}_{2} / \mathrm{MeOH}$ gradient with increasing amounts of $\mathrm{MeOH}$ from 5\% to $45 \%$ (total $15 \mathrm{~L}$ ) yielded 45 fractions $\left(\mathrm{Fr}_{\mathrm{D}-1}\right.$ to $\left.\mathrm{Fr}_{\mathrm{D}-45}\right)$. Fractions $\mathrm{Fr}_{\mathrm{D}-38}$ to $\mathrm{Fr}_{\mathrm{D}-41}$ were combined ( $24 \mathrm{~g}$ ) according to their TLC behaviour and chromatographed over silica gel $(770 \mathrm{~g})$, eluted with hexane/acetone $(3: 2,3 \mathrm{~L}$; $1: 1,3 \mathrm{~L}$; and $2: 3,3 \mathrm{~L})$, to yield 28 fractions $\left(\mathrm{Fr}_{\mathrm{D}-38-1}\right.$ to $\left.\mathrm{Fr}_{\mathrm{D}-38-28}\right)$. Fraction $\mathrm{Fr}_{\mathrm{D}-38-22}(2.5 \mathrm{~g})$ was re-chromatographed over silica gel (180 g), eluted with hexane/acetone $(4: 3,1 \mathrm{~L} ; 1: 1,1 \mathrm{~L}$; and $3: 4,1 \mathrm{~L})$, to afford 15 fractions $\left(\mathrm{Fr}_{\mathrm{D}-38-22-1}\right.$ to $\left.\mathrm{Fr}_{\mathrm{D}-38-22-15}\right)$. Fraction $\mathrm{Fr}_{\mathrm{D}-38-22-10}(76 \mathrm{mg})$ was subjected to pre- 
Table II. The ${ }^{1} \mathrm{H}$ and ${ }^{13} \mathrm{C}$ NMR data of 2 in $\mathrm{CDCl}_{3}\left(500 \mathrm{MHz}\right.$ for ${ }^{1} \mathrm{H}, 125 \mathrm{MHz}$ for $\left.{ }^{13} \mathrm{C}\right)$.

\begin{tabular}{|c|c|c|c|c|c|}
\hline Position & $\delta_{\mathrm{H}}\left(\mathrm{mult}^{\mathrm{a}}\right)$ & $J[\mathrm{~Hz}]$ & $\delta_{\mathrm{C}}^{\mathrm{b}}$ & HMBC & NOESY $^{\mathrm{c}}$ \\
\hline 1 & - & & 64.1 & & \\
\hline 2 & $4.82(\mathrm{~d})$ & 7.9 & 79.5 & $3,8,11,14,15,19$ & $16^{\mathrm{m}}, 17^{\mathrm{s}}, 19^{\mathrm{s}}, 20 \beta^{\mathrm{s}}$ \\
\hline 3 & $2.412(\mathrm{dd})$ & $7.9,1.5$ & 50.1 & & $5^{\mathrm{w}}, 7^{\mathrm{s}}, 14 \alpha^{\mathrm{s}}$ \\
\hline 4 & - & & 94.0 & & \\
\hline 5 & 4.27 (br.ddd) & $11.0,7.6,1.4$ & 71.5 & & $3^{\mathrm{w}}, 6 \alpha^{\mathrm{m}}, 6 \beta^{\mathrm{m}}, 7^{\mathrm{s}}$ \\
\hline $6 \alpha$ & $2.01(\mathrm{~m})$ & & 30.1 & & $5^{\mathrm{m}}, 7^{\mathrm{s}}, 6 \beta^{\mathrm{s}}, 20 \alpha^{\mathrm{s}}$ \\
\hline $6 \beta$ & $1.82(\mathrm{~m})$ & & & & $10^{\mathrm{s}}($ see 18$)$ \\
\hline 7 & $4.89(\mathrm{dd})$ & $12.8,4.8$ & 69.6 & $8,170.2$ & $3^{\mathrm{s}}, 5^{\mathrm{s}}, 6 \alpha^{\mathrm{s}}, 10^{\mathrm{m}}$ \\
\hline 8 & - & & 42.7 & & \\
\hline 9 & $4.83(\mathrm{~d})$ & 3.6 & 73.7 & $3,8,10,11,14,15,19,169.2$ & $10^{\mathrm{s}}, 16^{\mathrm{m}}, 17^{\mathrm{s}}, 19^{\mathrm{s}}$ \\
\hline 10 & 5.97 (d) & 3.6 & 69.8 & $1,8,9,11,12,168.8$ & $7^{\mathrm{m}}, 9^{\mathrm{s}}, 18^{\mathrm{s}}$ \\
\hline 11 & - & & 132.1 & & \\
\hline 12 & - & & 149.2 & & \\
\hline 13 & 4.68 (br.t) & 7.2 & 78.2 & & $14 \mathrm{a}^{\mathrm{s}}, 16^{\mathrm{s}}, 17^{\mathrm{m}}, 18^{\mathrm{s}}$ \\
\hline $14 \alpha$ & $1.92(\mathrm{dd})$ & $14.0,5.9$ & 38.3 & 1,15 & $3^{\mathrm{s}}, 14 \beta^{\mathrm{s}}$ \\
\hline $14 \beta$ & $2.49(\mathrm{dd})$ & $14.4,6.7$ & & 15 & $13^{\mathrm{s}}, 14 \alpha,{ }^{\mathrm{s}} 16^{\mathrm{s}}, 17^{\mathrm{s}}$ \\
\hline 15 & & & 87.1 & & \\
\hline 16 & $1.47(\mathrm{~s})$ & & 24.3 & $1,15, \mathrm{Me}-17$ & $2 / 9^{\mathrm{m}}, 13^{\mathrm{s}}, 14 \beta^{\mathrm{s}}, 17^{\mathrm{s}}, 18^{\mathrm{s}}$ \\
\hline 17 & $1.65(\mathrm{~s})$ & & 23.5 & $1,15, \mathrm{Me}-16$ & $2 / 9^{\mathrm{s}}, 13^{\mathrm{m}}, 14 \beta^{\mathrm{s}}, 16^{\mathrm{s}}$ \\
\hline 18 & $1.82(\mathrm{~s})$ & & 12.6 & $11,12,13$ & $10^{\mathrm{s}}, 13^{\mathrm{s}}, 16^{\mathrm{s}}$ (overlap with $6 \beta$ ) \\
\hline 19 & $1.39(\mathrm{~s})$ & & 14.5 & $3,7,8,9$ & $2 / 9^{\mathrm{s}}, 6 \beta^{\mathrm{s}}, 20 \beta^{\mathrm{s}}$ \\
\hline $20 \alpha$ & $4.37(\mathrm{~d})$ & 11.5 & 72.4 & 3,4 & $6 \alpha^{\mathrm{s}}, 20 \beta^{\mathrm{s}}$ \\
\hline $20 \beta$ & 3.65 (d) & 11.5 & & 4 & $2^{\mathrm{s}}, 19^{\mathrm{s}}, 20 \alpha^{\mathrm{s}}$ \\
\hline \multirow[t]{5}{*}{ Ac } & $2.14(\mathrm{~s})$ & & 22.1 & 169.2 & \\
\hline & $2.05(\mathrm{~s})$ & & 20.7 & 170.2 & \\
\hline & $1.99(\mathrm{~s})$ & & 20.9 & 198.8 & \\
\hline & $1.99(\mathrm{~s})$ & & 23.3 & 169.2 & \\
\hline & $2.00(\mathrm{~s})$ & & 21.1 & 170.0 & \\
\hline
\end{tabular}

Mutiplicity: s, singlet; d, doublet; dd, doublet of doublets; m, multiplet.

The ${ }^{13} \mathrm{C}$ chemical shifts were extracted from the HMQC experiment $( \pm 0.2 \mathrm{ppm})$.

NOESY intensities are marked as strong (s), medium (m), or weak (w).

parative TLC $(3 \times 20 \times 20 \mathrm{~cm}$, thickness $0.5 \mathrm{~mm})$ developed with $\mathrm{CH}_{2} \mathrm{Cl}_{2} / \mathrm{CH}_{3} \mathrm{CN}$ (8:5). The zone located at $R_{\mathrm{f}}=0.47$ under UV light was scraped, harvested, and washed with acetone and further purified by preparative TLC $(1 \times 20 \times 20 \mathrm{~cm}$, thickness $0.25 \mathrm{~mm}$ ) developed with hexane/acetone (2:3). It finally provided $1\left(2.4 \mathrm{mg} ; R_{\mathrm{f}}=0.34\right.$; $[\alpha]_{\mathrm{D}}^{22}+8^{\circ}\left(c 0.1, \mathrm{CHCl}_{3}\right)$ and $2\left(1.3 \mathrm{mg} ; R_{\mathrm{f}}=0.45\right.$; $[\alpha]_{\mathrm{D}}^{22}+11^{\circ}\left(c 0.1, \mathrm{CHCl}_{3}\right)$ as amorphous solids.

\section{Cytotoxicity assay}

The human tumour cell lines used were as follows: HeLa (cervical cancer cell line), HEC-1 (endometrial adenocarcinoma cell line), SHIN3 (ovarian clear-cell cystadenocarcinoma cell line), HOC-21 (ovarian clear-cell cystadenocarcinoma cell line), HAC-2 (ovarian clear-cell carcinoma cell line), HLE (hepatoma cell line), U251-SP (glioma cell line), T-98 (glioma cell line), MM1CB (melanoma cell line), HMV-1 (melanoma cell line) and KT (breast carcinoma cell line) (Suzuki and Fuse, 1984; Suzuki et al., 1995). Cells were cultured in Eagle's minimal essential medium (EMEM) (GIBCO/BRL, Grand Island, NY, USA), containing $10 \%(\mathrm{v} / \mathrm{v})$ calf serum (Intergen, Purchase, NY, USA) and antibiotics $(100 \mu \mathrm{g} / \mathrm{mL}$ of streptomycin and 100 units $/ \mathrm{mL}$ of penicillin G) (Meiji Seika, Tokyo, Japan), at $37^{\circ} \mathrm{C}$ in a humidified atmosphere containing $5 \% \mathrm{CO}_{2}$. Cell survival was estimated by the MTT assay as described elsewhere (Zhai et al., 2005). Briefly, logarithmically proliferating cells were plated into 96-well plates $\left(1 \cdot 10^{4}\right.$ cells/well $)$ with the medium containing the test compounds at the indicated doses, followed by culture for $2 \mathrm{~d}$. After the culture, the activity of mitochondrial succinic dehydrogenase was measured by further incubation of the cells 
with $0.5 \mathrm{mg} / \mathrm{mL}$ MTT (Sigma) for $4 \mathrm{~h}$, followed by estimation of the absorbance at $570 \mathrm{~nm}$ with a reference wavelength of $655 \mathrm{~nm}$. Cell viability was calculated from the absorbance as percentage of the survived cells.

\section{Acknowledgements}

The work reported in the present paper was financially supported by the Foundation for Researching New Drugs of People's Republic of China (No. 2003AA2Z3527) and Scientific Re-

Appendino G. (1995), Naturally occurring taxoids. The structural elucidation of taxoids. In: The Chemistry and Pharmacology of Taxol and its Derivatives Vol. 22 (Farina V., ed.). Elsevier Science, Amsterdam, pp. $1-53$ and pp. 55-101.

Baloglu E. and Kingston D. G. I. (1999), Taxane diterpenoids. J. Nat. Prod. 62, 1448-1472.

Dong M., Zhang M.-L., Shi Q.-W., Gu Y.-C., and Kiyota H. (2008), Chemical constituents in Taxus canadensis. In: Natural Products: Chemistry, Biochemistry and Pharmacology, Chapter 9 (Brahmachari G., ed.). Narosa Publishing House PVT. LTD., New Delhi, India, pp. 247-269.

Fuji K., Tanaka K., Li B., Shingu T., Yokoi T., Sun H. D., and Taga T. (1995), Structures of nine new diterpenoids from Taxus chinensis. Tetrahedron 51, 10175-10188.

Shen Y. C., Chang Y. T., Lin Y. C., Lin C. Y., Cuo Y. H., and Chen C. Y. (2002), New taxane diterpenoids from the roots of Taiwanese Taxus mairei. Chem. Pharm. Bull. 50, 781-787.

Shen Y. C., Cheng K. C., Lin Y. C., Cheng Y. B., Khalil A. T., Guh J. H., Chien C. T., Teng C. M., and Chang Y. T. (2005), Three new taxane diterpenoids from Taxus sumatrata. J. Nat. Prod. 68, 90-93. search Foundation for the Returned Overseas Chinese Scholars of Hebei Province and State Education Ministry of P. R. China (QWS). We also appreciate the financial support by Syngenta Ltd. (2005-Hebei Medical University-Syngenta-01) and a grant-in-aid from Japan Society for the Promotion of Science (No. 19580120). We are pleased to thank Prof. Nobuo Suzuki (Department of Environmental Biochemistry, Chiba University, Japan) for providing the cells for the biological evaluation.

Shi Q.-W. and Kiyota H. (2005), New natural taxane diterpenoids from Taxus species since 1999. Chem. Biodivers. 2, 1597-1623.

Shi Q.-W., Wang Y.-F., and Kiyota H. (2007), Phytochemical studies of taxane diterpenoids from yew trees. In: Chemistry of Natural Products: Recent Trends and Developments, 2006 (Brahmachari G., ed.). Research Signpost, Kerala, India, pp. 43-59.

Suzuki N. and Fuse A. (1984), UV-sensitive human clonal cell line, RSa, which has low repair activity. Mutat. Res. 84, 133-145.

Suzuki N., Sekiya S., Sugano I., Kojima T., Yamamori H., and Takakubo Y. (1995), Dipyridamole combined with tumour necrosis factor-a enhances inhibition of proliferation in human tumour cell lines. Jpn. J. Cancer Res. 86, 761-769.

Zhai L., Kita K., Wano C., Wu Y., Sugaya S., and Suzuki N. (2005), Decreased cell survival and DNA repair capacity after UVC irradiation in association with down-regulation of GRP78/BiP in human RSa cells. Exp. Cell Res. 305, 244-252.

Zhang H., Tadeda Y., and Sun H. D. (1995), Taxanes from Taxus yunnanensis. Phytochemistry 39, 1147-1151. 